\title{
Never Let Me Down: A Case-study of Slovenian Policy Measures to Prevent Early School Leaving
}

Dr. Danijela Makovec

\author{
Assistant Professor, \\ Department for Educational Sciences, \\ Faculty of Arts, University of Ljubljana

\section{Dr. Marko Radovan} \\ Associate Professor, \\ Department for Educational Sciences, \\ Faculty of Arts, University of Ljubljana
}

Doi: 10.2478/mjss-2018-0126

\begin{abstract}
In this article, we discuss the factors that influence early school leaving, and the measures that were taken in Slovenia to prevent it. Reducing early school leaving (ESL) to less than $10 \%$ by 2020 is one of the key objectives of the Europe 2020 strategy and Slovenia is already well below this target. According to recent analysis, Slovenia has one of the lowest rate of ESL among EU countries. In our review we will examine the reasons for such a low ESL rate and inspect institutional and policy measures that Slovenia has undertaken in order to reduce ESL and retain students in education as long as possible. We argue that Slovenia is successful in reducing ESL because of a wide-spread network of secondary schools, and measures that are directed in individualization, guidance and support for less successful students. In our estimation, one of the main reasons for the low rate of ESL in Slovenia is also the openness of vocational education system, that allows horizontal and vertical transitions. An area that needs additional attention from policy makers, concerns high-risk groups of students. There is also a need for teachers to develop additional inter-cultural and communication competencies, and schools should receive more funding for Slovenian language courses, working with the Roma, programs individualization for special needs students, extended schooling for students with special needs etc.
\end{abstract}

Keywords: early school leaving; dropout; educational policy; engagement; social background, European Union; Slovenia

\section{Introduction}

Studies show that early school leaving (also known as "early leaving from education and training"; ESL) is a multifaceted and complex phenomenon that does not occur suddenly, but is the result of a continuous process of academic failures (Banerjee, 2016; Cairns, Cairns, \& Neckerman, 1989). Official EU reports define ESL as those "... aged 18 to 24 who has completed at most lower secondary education and is not involved in further education or training" (Eurostat Glossary, 2016). Various factors can be attributed as the causes of ESL; e.g., the individual's characteristics, his or her family, and their social or economic conditions (Dekkers \& Claassen, 2001; Rumberger, 1983). The number of articles on this topic has increased and the understanding on why some students leave school early has grown. Numerous authors note that definitions of early leaving education in the research literature are very different (Markussen et. al., 2011). They reflect different reasons for 
leaving education and national contexts of examining this phenomenon. Reducing early school leaving to less than $10 \%$ by 2020 is one of the key objectives of the Europe 2020 strategy and Slovenia is in 2017 with $4.9 \%$ well below this target. In this article, we review the main research finding of factors influencing ESL and summarize their main characteristics in Slovenia. For the research different methods for the collection of data were used. The main part research was carried out through the analysis of documentation (strategies, legislation, reports, etc.) that were available online or in the records of the institutions they published (e.g. the Ministry of Education, Science and Sport). We obtained quantitative data on the ESL levels for individual countries and/or Slovenia on the Eurostat (2017) website. Furthermore, we list some systemic and preventive measures, which are aimed at reducing the social exclusion of vulnerable groups of young people in Slovenia. Possible other reasons for the low ESL rate are also examined.

\section{Determinants of ESL}

The vast volume of previous research on this topic in previous years has increased the understanding on why some students drop-out or leave school early. Firstly, we must mention that the definitions of early leaving education in the research literature are very different and reflect different reasons for leaving education in the national contexts of examining this phenomenon (Markussen et. al., 2011). Many previous studies tried to determine the general context that influenced someone's decision to leave or not to continue his or her schooling (Alivernini \& Lucidi, 2011; Cederberg \& Hartsmar, 2013; De Witte et al., 2013; Fernández-Macías, Antón, Braña, \& De Bustillo, 2013; Lamb, Markussen, Teese, Sandberg, \& Polesel, 2011). These studies came to the conclusion that ESL is the interaction of many complex variables and that it is often difficult to determine which is more important at a given moment. ESL can be caused by the following factors: attitudes of parents towards school, low culture, unfavorable living conditions, lower cognitive ability, specific learning difficulties, and poor health status. In general, factors can be classified as determinants of individual differences, family origin, and school environment. There were several attempts to determine individual characteristics of students that could potentially leave education. According to some studies early school leavers are less intelligent and perform worse in school tests as compared to students who do not leave school (Audas \& Willms, 2002; Cairns et al., 1989; Ensminger \& Slusarcick, 1992). Furthermore, they have a tendency to be not-motivated for school work and are not feeling good in school (Hoffman \& Lowitzki, 2005). Studies found that males and ethnic minorities have the highest risk to leave education early (Dekkers \& Claassen, 2001; Marks \& Fleming, 1999). A powerful determinant of early school-leaving is also family background. As noted by Rumberger (1983), it is more likely that economically deprived students, whose parents are less educated will not successfully complete their schooling.

Studies find that a positive social climate, a sense of belonging to the school and the high degree of cooperation between pupils, teachers and parents are among those factors that contribute to lower dropout rate (De Witte et al., 2013; Markussen, Frøseth, \& Sandberg, 2011). Many reliable and current results also indicate a close relationship between school failure, dropout, and grade retention. These are the results that are of utmost importance for predicting school success. The report on seventeen studies in the US (Jimerson, Anderson, \& Whipple, 2002), empirically confirmed that the decline in student's school success correlated with the extent of truancy; therefore, regular school attendance can be considered as a safety factor of school performance. At the same time there are also important lessons learned from research done by Stearns et al. (2007), that greater control over student absenteeism and supervision of their school work at home rarely reinforce negative phenomena, such as fear of school, aversion to school, and dropout.

\section{Research of Dropouts and School Leaving in Slovenia}

There are some meaningful insights that helped us determine the profile of "potential" early school leavers in Slovenia. They are coming from national studies that tried to determine factors that influence school performance in Slovenian vocational education and consequent leaving of 
education (Geržina et al., 2001; Klanjšek, Flere, \& Lavrič, 2007; Ule, Kuhar, \& Kožar Černelič, 2003). According to Geržina et al. (2001), the earliest recorded student dropout occurred back in elementary school itself. These are particularly those pupils who fulfil elementary 'school obligation' defined by law (9 years of schooling), but do not continue schooling at the secondary level. Their research show, that the highest dropout rate in vocational education was in the 2-year short vocational upper secondary programs $(31.9 \%$ in year 1993). Between years 1991 and 1993, the dropout rate increased by $10 \%$. The 2-year short vocational upper secondary programs also enroll students who had not completed primary school (but have done compulsory schooling) and students who attended elementary school with a tailor-made program.

Surveys, conducted on the sample of young people who dropped out of secondary education, have shown that the following characteristics mostly characterize dropouts:

- low socio-economic status of the families from which they come;

- lack of incentives from parents;

- poor relationships with parents;

- perception that teachers' attitude is worse toward them than towards the more successful students (Ule, 2003, p. 67).

A more recent analysis of factors that influence school success in secondary school showed that school performance in primary school is highly associated with success at the end of the first year of secondary school (Klanjšek et al., 2007). The figures in the study, in which 1000 students were enrolled, point out that the factors of school success in vocational education are developed early in childhood. The variables that were significantly associated with the achievements in primary school were: sex (on average, boys have lower school success), intelligence, locus of control, education of mother, attachment and trust between children and parents, family size and structure, economic status, study help received, and student's cultural capital. We must also mention social anxiety, the importance of which was shown clearly only at the secondary level schooling. Also relevant is the student's attachment to school, which mainly refers to his or her positive emotional attitudes towards school (Klanjšek et al., 2007). It is difficult to talk about the direct correlation between the quality and duration of compulsory education and dropout, but it is certainly true that students, who are less successful in primary school, are also more prone to drop out in secondary education. As we already mentioned, the largest dropout rate in secondary schools was recorded in 2-year short vocational upper secondary programs (Geržina et al, 2001).

\section{Policy Measures and Institutional Initiatives for Preventing ESL in Slovenia}

Experts identify that schools play an important role in reducing ESL, but their work cannot take place without the support of policies and measures at the level of the education system. Empirical, and real-life evidence, identify that the most effective are integrated approaches that focus on the root causes of ESL (Alivernini \& Lucidi, 2011; European Commission/EACEA/Eurydice/Cedefop, 2014; Marks \& Fleming, 1999). It is possible to reduce ESL only with comprehensive strategies that address the entire education spectrum and include prevention, intervention and compensation measures. While preventing ESL, it needs initiatives at system level and is tightly connected to the pre-conditions for successful schooling and the design of education and training systems (e.g. a stimulating learning environment for learning); intervention usually takes place at the level of individual schools and requires tools and mechanisms for early detection of support, needed for learning and motivation. Compensation measures are aimed towards young people who have had their education interrupted due to various reasons and aim to reengage people in education and training.

Current Eurostat data show that Slovenia is among countries with the lowest levels of earlyschool leavers. Eurostat data demonstrate, that the percentage of students in the age group 18-24 that left education and training was $4.1 \%$ in 2007 and $4.9 \%$ in 2016 (Eurostat, 2017). This is much lower than the average of $11 \%$ in all $28 \mathrm{EU}$ countries, and one of the lowest ESL rate in EU. 


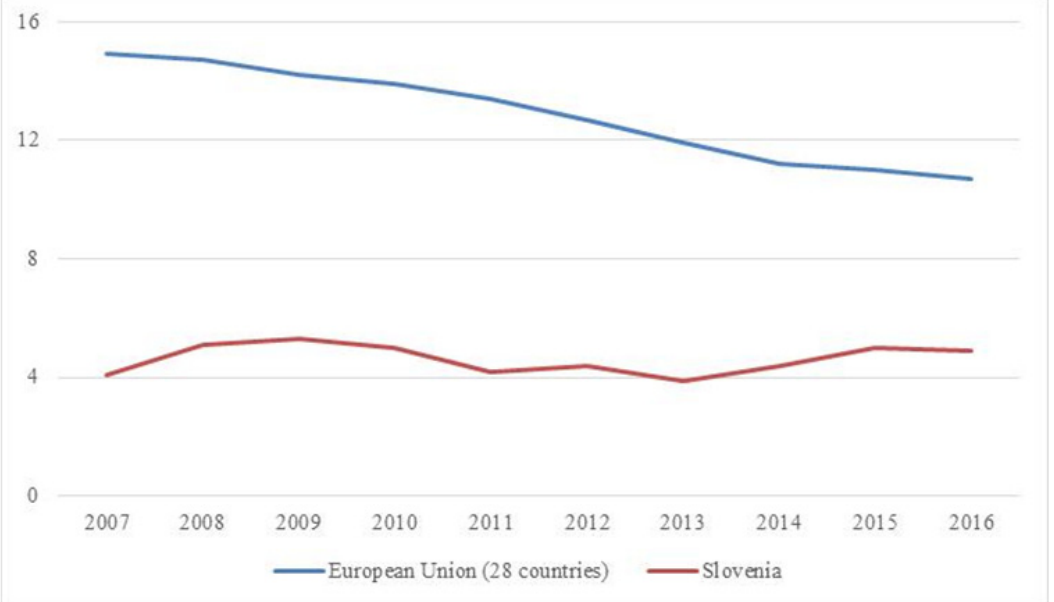

Figure 1. Trends of Early School Leavers Rate in Slovenia and EU28

Source: Eurostat, 2017

We can name several indicators in the Slovenian education system that can lead to low levels of ESL. It ranges from broader, policy and system changes, to "small", institutional measures that helps young people to overcome their educational or personal barriers.

\subsection{Education reform in the 90s}

Firstly, we must mention that in the second half of the nineties in Slovenia, an educational reform was carried out which led to the renovation of vocational and technical education where the existing programs were either updated or replaced. Throughout the reform, a significant number of new programs were introduced at all levels of vocational education that would allow students to get into a profession that would meet the needs of the labor market. In accordance with the reform, the expansion of the school network had also been implemented. The number of schools that implemented the same programs was increased. Following this reform, schools are also more geographically dispersed, and from this perspective, also more accessible to young people. The number of secondary schools decreased between 2000 and 2010 and, the number of students was reduced as well. The schools also vary in their organization and content. Smaller schools were merged in the 'School Centres' and with the changes in the economy the content/program structure were also changed (Černoša, 2012).

\subsection{Active Employment Policy}

Leaving from education is highly correlated with youth unemployment. High youth unemployment in the country is one of the most important challenges for Slovenia. The proportion of unemployed in the general labor force was $12 \%$ at the end of 2012 , which means that almost 120,000 people were unemployed (Slovenia Employment Service, 2015). Unemployment structure is also worrying; Almost half of them (45.6\%) are registered as unemployed for more than a year (long-term unemployed), more than a third (34.4\%) are poorly qualified (primary school or lower), $15 \%$ are first job seekers, one third (34\%) is over 50 and $11.7 \%$ are under 25 years old.

In Figure 2 the unemployment rates of young people from 15-24 years old are presented. Data from 2007 to 2017 show that youth unemployment in Slovenia has been increasing since the beginning of the economic crisis, and in 2013 it climaxed at 22 percent. After that these trends started to decrease, but it is still higher than before the crisis and confirms the vulnerability of young people in the labor market. 


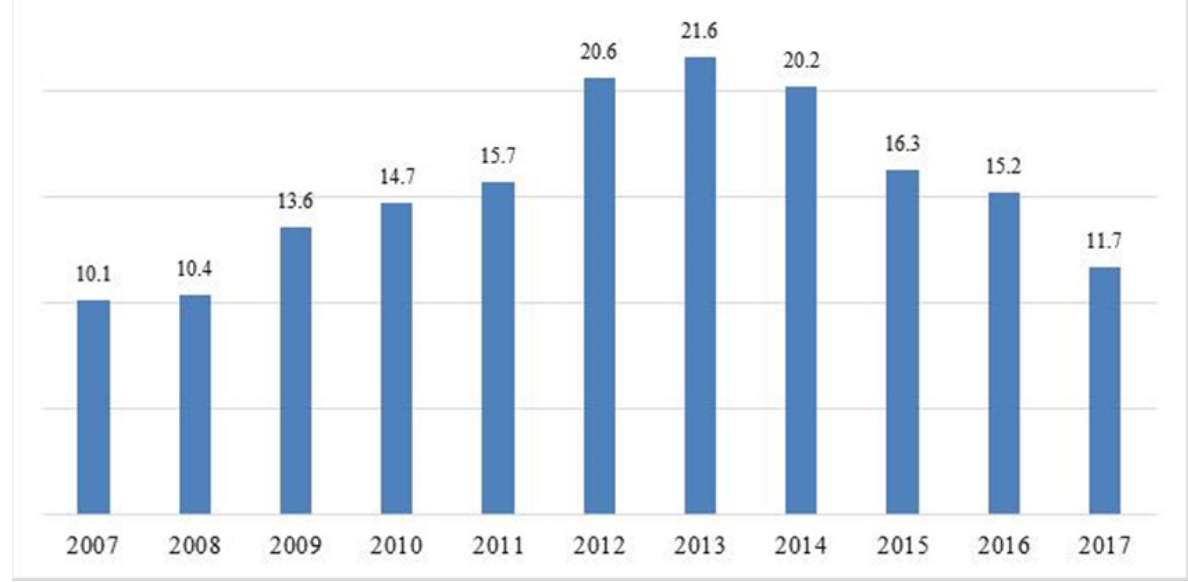

Figure 2. Youth unemployment rate - $\%$ of active population aged $15-24$

Source: Eurostat, 2018, Table: tipsIm80

Most of the unemployed, registered with the Employment Service for 1 year or more, have (un)finished elementary school, and at this level, account for nearly two-thirds $(62.8 \%)$ of the longterm unemployed (Employment Service of Slovenia, 2017, p. 20). Although the low level of education is not a serious problem for young unemployed people in Slovenia, those who have left education and need new skills have different opportunities to acquire knowledge and skills. Most of these are offered under the "Active Employment Policy" measures of the Ministry of Labor, Family and Social Affairs. They include upper secondary education and also re-training or updating skills.

\subsection{The Youth Guarantee Strategy}

An important policy measure for tackling early-school leaving is "Youth Guarantee" (YG) program that is implemented in Slovenia since 2014 and ensures that every person between 15 and 29 years old is offered an opportunity for employment, some kind of training (job-related, skill-focused or formal) within four months of registering as unemployed with the Employment Service of Slovenia. According to "Youth Guarantee country by country-Slovenia" (2017) report, there has been a decrease in youth unemployment in Slovenia in all age groups. Unemployment among young people has increased as a result of the introduction of this program, also report show that YG participants received $40 \%$ more recommendations than those who did not participate in the scheme, 10 times more employers and $70 \%$ more training (ibid.).

\subsection{Counseling and guidance services as a backbone of preventive and curative measures for reducing ESL}

At the policy level, one of the most important preventive measures to reduce early school leaving in Slovenia is included in the "Organization and Financing of Education Act" (2007) which obliges every kindergarten and school to provide a guidance service for children, pupils, apprentices, students, teachers and parents. Thus, school guidance plays an important role in the context of career guidance, where it aids the pupils in making a decision about their schooling in the future, where an individual's professional interest, his/her academic performance, and the schools/programs available are in the foreground, while the provision of vocational guidance is carried out with the collaboration with the National Employment Service.

Similar to the primary school is counselling in middle schools, where one of the general areas 
of counselling services is determined in the document "Program guidelines - Counselling Service in gymnasiums, vocational and technical upper secondary schools and boarding schools" (Čačinovič Vogrinčič et al., 2008). These guidelines emphasize that one of the main areas of counselling in secondary education should be focused on "special care at accepting, monitoring and advising newcomers, repeaters, redirected, integrated students, as well as students in transition to the next level of education and career guidance" (Čačinovič Vogrinčič et al, 2008, p. 17). In addition to counselling services, which are available every day for students in schools, there is a variety of counselling services at the employment services, other public or private non-profit institutions, and web portals, where young people and their parents can find information on careers and education. These services are aimed at young people and all others who seek information for planning their educational career or employment and can operate as both preventive and also remedial measures.

Another important complementary activity for system-wide measures for preventing early school-leaving is the development of adult education guidance centers involving 14 regional guidance centers with almost sixty dislocated units. This network was formed in 2008, and they provide information and counselling for adults of all ages about the possibilities of education and preparing individual educational plans or give advice about the available educational programs. In addition, these centers have 160 discrete units ("Points of Lifelong Learning") targeted at young adults, the unemployed, and seniors who perform numerous educational activities throughout the country and in which about 36,000 participants are included every year (Barle Lakota \& Černoša, 2011).

\subsection{Gaining qualification outside of the school system}

For students who leave education in spite of the before mentioned policy measures, there are programs available to obtain both formal education and qualifications. They have the opportunity to gain formal education as an adult participant (secondary schools offer vocational programs also for adults, which are payable). Those who choose to not obtain a formal level of education may validate their knowledge through the acquisition of National Vocational Qualifications (NVQs). This instrument is intended for individuals without any completed formal schooling, but who have acquired various vocational competencies throughout their lifetime. In each educational program, it is determined which modules are available for professional certification. According to the 2016 information from the National Reference Point for Occupational Qualifications, there are 263 NVQs catalogues available, and the number of obtained NVQs among population between the ages of 18 and 24 years is increasing. In 2009, this age group acquired 153 NVQs, and in 2013 this number increased to 665 .

\subsection{Curative initiatives that reduce ESL from VET}

One of the main curative measures for young people who left education is a project called "Youth Project Learning" (YPL). YPL is a 1-year verified program of non-formal education and was formally introduced by the decree of the Minister of Education and Sport in 1999. The program is aimed at young people aged 15 to 25 years who have left education and have no occupation or job. In the school year 2010/2011, the program was conducted by 11 organizations, and each year, about 180 young people are included in these programs. The program offers project work and a different approach to education of young adults, and ensures they remain in the program for the long term. The effects of learning in the program are evident in carrying out missing exams for continuing education or in filling the gaps in knowledge that arose during their formal education. Past experience in the YPL program, indicates that it encourages younger participants to complete the education they had previously abandoned, which leads to the successful development of professional or employment strategies. Research has shown that every year $60-70 \%$ of the YPL participants re-engage in education or are employed. Similar goals can be seen in the program of "Production School" that targets groups of young people who have completed their primary obligation and are aged between 15 and 18 years old. "Production School" is helping young people 
with various problems to return into the education system or supports their entrance to the labor market. On the one hand, they enable youngsters to acquire appropriate attitudes, knowledge, and experiences, and on the other hand they offer advice to parents in order to adjust their educational expectations and requirements.

\section{Conclusions}

In this article we analyzed early school leaving in Slovenia, its systemic characteristics, and measures that, in our opinion, reduce it. The task of reducing early leaving from education is one of the most important topics among EU's strategies, since it is believed that it helps to overcome unemployment and improve access to education. Data show that Slovenia is a "success story" when talking about ESL, since international data show that Slovenian ESL rates are among the lowest in EU. Nevertheless, necessary measures for retaining students in schools should be implemented and preserved. This is also in accordance with government policy, which stresses the concern for the dropouts and those leaving the education system as early as possible necessary (Barle Lakota et al., 2011). There is evidence presented in this article indicating that currently measures are directed in individualization of education, guidance and support for less successful students, and developing methods and strategies that support the development of competencies to be successful in education. It is our assessment, that main reasons for the low rate of ESL cannot be find only in student-centered activities and initiatives, but are also a reflection of systemic openness of vocational education in Slovenia. In this system students after each level of education, have a possibility to choose among many paths to continue their education vertically "up" to tertiary education or "down" to less demanding vocational programs. In our opinion, this is a very important safeguard, which allows the student to adapt their educational path and, consequently, reduce the dropout out of education. The system also allows horizontal mobility within the vocational education and training systems, permits the corrections of "wrong decisions" in choosing secondary education program. In this way, the student can choose the educational program he is really interested in, and is consequently more motivated, persistent and diligent. Although, there are fewer opportunities for transition from vocational to general education (Gymnasiums), the possibility of transition to tertiary education is not closed.

The next important reason for low ESL rates in Slovenia lies also in the rich and diverse school network system. Many secondary schools (or school centers) in Slovenia carry out contentrelated programs at different ISCED levels. This means that students, who are not successful in more demanding programs (ISCED 3) have the opportunity to switch to lower, less demanding programs (ISCED 2). In this way do they not drop-out from school but have "a second chance" to continue their education and gain a certain level of formal education. This may also be one of the reasons why previous research found dropout rates to be highest in the 2-year short vocational upper secondary programs (Geržina et al., 2001; Ule, Kuhar, \& Kožar Černelič, 2003).

We conclude that Slovenian system of education and policy measures efficiently impact young people's continuation of education. Despite the low level of early school-leaving, we are calling for the introduction of more preventive measures, such having the educational system to better adapt to the needs of young people, young people's active participation in the design of such processes and encourage young people's positive attitudes towards education with appropriate career guidance. One of the measures at the institutional and national levels could have definitely been improving school climate, which some authors understand as the hidden explanatory factor of differences in school performance (Jimerson et al., 2002; Stearns et al., 2007). This may be related to the method of regulation of education, creating less rigid atmosphere, better collective and team working climate etc. This is especially important, since the "attachment to school" was found as one of the important factors for preventing early school leaving (De Witte et al., 2013; Markussen, Frøseth, \& Sandberg, 2011). An area that needs additional attention from policy makers, concerns high-risk groups of students (e.g., young people with disabilities, migrants). Teachers should develop competencies to work with diverse, intercultural groups of students, and schools should receive more funding for Slovenian language courses, working with the Roma, programs individualization for special needs students, extended schooling for students with special needs etc. 


\section{References}

Alivernini, F., \& Lucidi, F. (2011). Relationship between social context, self-efficacy, motivation, academic achievement, and intention to drop out of high school: A longitudinal study. The Journal of Educational Research, 104(4), 241-252.

Audas, R., \& Willms, J. D. (2002). Engagement and dropping out of school a life-course perspective. Hull, Quebec: Applied Research Branch, Human Resources Development Canada.

Banerjee, P. A. (2016). A systematic review of factors linked to poor academic performance of disadvantaged students in science and maths in schools. Cogent Education, 3(1), 1178441. https://doi.org/10.1080/2331186X.2016.1178441

Barle Lakota, A., \& Černoša, S. (2011). National report of the Republic of Slovenia on the implementation of the strategic framework for European cooperation in education and training (ET2020) (unpublished report). Ljubljana: Ministrstvo za šolstvo in šport.

Čačinovič Vogrinčič, G., Bregar Golobič, K., Bečaj, J., Pečjak, S., Resman, M., Bezić, T., \& et al. (2008). Programske smernice. Svetovalna služba $v$ gimnazijah, nižjih in srednjih poklicnih šolah ter strokovnih šolah in v dijaških domovih [Program guidelines. Counseling services in general upper secondary schools and in short, vocational and technical upper secondary schools and in student dorms]. Ljubljana: Zavod Republike Slovenije za šolstvo.

Cairns, R. B., Cairns, B. D., \& Neckerman, H. J. (1989). Early School Dropout: Configurations and Determinants. Child Development, 60(6), 1437-1452. https://doi.org/10.2307/1130933

Cederberg, M., \& Hartsmar, N. (2013). Some Aspects of Early School Leaving in Sweden, Denmark, Norway and Finland. European Journal of Education, 48(3), 378-389. https://doi.org/10.1111/ejed.12036

Černoša, S. (2012). Razvoj sistema izobraževanja v Sloveniji v luči uresničevanja skupnih evropskih ciljev analiza uresničevanja ciljev "Izobraževanje in usposabljanje 2010" 2000-2010 [The development of the education system in Slovenia in light of implement the common European objectives: Analysis of achieving the objectives of "Education and Training 2010" 2000-2010]. Ljubljana: Pedagoški inštitut.

Commission of the European Communities. (2009). Progress towards the Lisbon objectives in education and training. Indicators and benchmarks 2008. (No. SEC (2008) 2293). Brussels: European Commission.

De Witte, K., Nicaise, I., Lavrijsen, J., Van Landeghem, G., Lamote, C., \& Van Damme, J. (2013). The Impact of Institutional Context, Education and Labour Market Policies on Early School Leaving: a comparative analysis of EU countries. European Journal of Education, 48(3), 331-345. https://doi.org/10.1111/ejed.12034

Dekkers, H., \& Claassen, A. (2001). Dropouts - disadvantaged by definition? A study of the perspective of very early school leavers. Studies in Educational Evaluation, 27(4), 341-354. https://doi.org/10.1016/S0191491X(01)00034-7

Employment Service of Slovenia. (2015). Mladi in trg dela [Youth and the Labour Force]. Ljubljana: Employment Service of Slovenia.

Employment Service of Slovenia. (2017). Strokovna izhodišča za leto 2018 [Expert starting points for 2018]. Ljubljana: Employment Service of Slovenia.

Ensminger, M. E., \& Slusarcick, A. L. (1992). Paths to High School Graduation or Dropout: A Longitudinal Study of a First-Grade Cohort. Sociology of Education, 65(2), 95-113. https://doi.org/10.2307/2112677

European Commission. (2011). Progress Towards the Common European Objectives in Education and Training. Indicators and Benchmarks 2010/2011. Strasbourg: European Commission. Retrieved from http://ec.europa.eu/education/lifelong-learning-policy/indicators 10 en.htm

European Commission/EACEA/Eurydice/Cedefop. (2014). Tackling Early Leaving from Education and Training in Europe: Strategies, Policies and Measures. Luxembourg: Publications Office of the European Union.

Eurostat. (2017, September 1). Early leavers from education and training by sex and labour status (online table code: edat Ifse 14). Retrieved from http://appsso.eurostat.ec.europa.eu/nui/submitViewTableAction.do

Eurostat Glossary: Early leaver from education and training. (2016, April 13). Retrieved February 15, 2018, from http://ec.europa.eu/eurostat/statistics-

explained/index.php/Glossary:Early_leaver_from_education_and_training

Fernández-Macías, E., Antón, J.-I., Braña, F.-J., \& De Bustillo, R. M. (2013). Early School-leaving in Spain: evolution, intensity and determinants. European Journal of Education, 48(1), 150-164. https://doi.org/10.1111/ejed.12000

Geržina, S., Vranješ, P., Cek, M., Hazl, V., Mesec, P., \& Švab, A. (2001). Modernisation of vocational education and training: national report, Slovenia 2000. Ljubljana: National VET Observatory Slovenia, Centre of the Republic of Slovenia for Vocational Education and Training.

Hoffman, J. L., \& Lowitzki, K. E. (2005). Predicting College Success with High School Grades and Test Scores: Limitations for Minority Students. Review of Higher Education, 28(4), 455-474. https://doi.org/10.1353/rhe.2005.0042 
Jimerson, S. R., Anderson, G. E., \& Whipple, A. D. (2002). Winning the battle and losing the war: Examining the relation between grade retention and dropping out of high school. Psychology in the Schools, 39(4), 441457. https://doi.org/10.1002/pits. 10046

Klanjšek, R., Flere, S., \& Lavrič, M. (2007). Kognitivni in družbenoekonomski dejavniki šolskega uspeha v Sloveniji. Družboslovne Razprave, 23(55), 49-69.

Lamb, S., Markussen, E., Teese, R., Sandberg, N., \& Polesel, J. (Eds.). (2011). School dropout and completion: international comparative studies in theory and policy. Dordrecht: Springer.

Marks, G. N., \& Fleming, N. (1999). Influences and Consequences of Well-being Among Australian Young People: 1980-1995. Social Indicators Research, 46(3), 301-323. https://doi.org/10.1023/A:1006928507272

Markussen, E., Frøseth, M. W., \& Sandberg, N. (2011). Reaching for the unreachable: Identifying factors predicting early school leaving and non-completion in Norwegian upper secondary education. Scandinavian Journal of Educational Research, 55(3), 225-253.

Organisation and Financing of Education Act. (2007). Official Bulletin of the RS, (16//2007).

Rumberger, R. W. (1983). Dropping Out of High School: The Influence of Race, Sex, and Family Background. American Educational Research Journal, 20(2), 199-220. https://doi.org/10.3102/00028312020002199

Rumberger, R. W. (1995). Dropping Out of Middle School: A Multilevel Analysis of Students and Schools. American Educational Research Journal, 32(3), 583-625. https://doi.org/10.3102/00028312032003583

Stearns, E., Moller, S., Blau, J., \& Potochnick, S. (2007). Staying Back and Dropping Out: The Relationship Between Grade Retention and School Dropout. Sociology of Education, 80(3), 210-240. https://doi.org/10.1177/003804070708000302

The Youth Guarantee country by country - Slovenia (2017). Strasbourg: European Commission.

Ule, M., Kuhar, M., \& Kožar Černelič, S. (2003). Kakovost življenja otrok in mladostnikov v Sloveniji: projektna naloga: študija problema osipništva $v$ Sloveniji: zaključno poročilo [Quality of life of children and adolescents in Slovenia: Project: Study the problem of early school leaving in Slovenia: Final report]. Ljubljana: Fakulteta za družbene vede. 